\title{
RETRACTED ARTICLE: Inhibition of miR-296-5p protects the heart from cardiac hypertrophy by targeting CACNG6
}

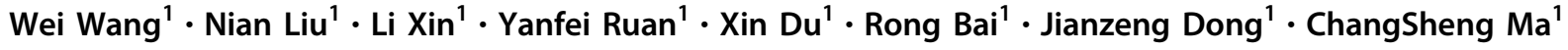

Received: 19 May 2019 / Revised: 23 September 2019 / Accepted: 16 October 2019 / Published online: 16 December 2019

(c) The Author(s) 2019. This article is published with open access

The Editor-in-Chief has retracted this article [1] due to concerns regarding the figures and the underlying data. The authors informed the journal that they have not been able to reproduce the results presented in the article. Further investigation found significant text overlap with an article by different authors that was simultaneously under consideration at the same time at another journal [2]. Additionally, there appear to be overlapping figures between the two articles:

The bottom left two panels of Figure 4F of [1] appear to be identical to the bottom left and bottom right panels of Figure 2B of [2]

The TAC panel in Figure 4G of [1] TAC image appears to be a reflection (y axis) of the TAC+control in Figure 4G of [1].

The data reported in this article are therefore unreliable Changsheng Ma agrees to this retraction. The other authors have not responded to correspondence regarding this retraction.

The online version of this article contains the full text of the retracted article as electronic supplementary material.
Open Access This article is licensed under a Creative Commons Attribution 4.0 International License, which permits use, sharing, adaptation, distribution and reproduction in any medium or format, as long as you give appropriate credit to the original author(s) and the source, provide a link to the Creative Commons license, and indicate if changes were made. The images or other third party material in this article are included in the article's Creative Commons license, unless indicated otherwise in a credit line to the material. If material is not included in the article's Creative Commons license and your intended use is not permitted by statutory regulation or exceeds the permitted use, you will need to obtain permission directly from the copyright holder. To view a copy of this license, visit http://creativecommons. org/licenses/by/4.0/.

\section{References}

1. Wang, W., Liu, N., Xin, L. et al. Inhibition of miR-296-5p protects the heart from cardiac hypertrophy by targeting CACNG6. Gene Ther (2019). https://doi.org/10.1038/s41434-019-0109-0.

2. Xu L, Wang H, Jiang F, Sun H, Zhang D. LncRNA AK045171 protects the heart from cardiac hypertrophy by regulating the SP1/ MG53 signalling pathway. Aging (Albany NY). 2020; 12:31263139. https://doi.org/10.18632/aging.102668.
Supplementary Information The online version of this article (https://doi.org/10.1038/s41434-019-0109-0) contains supplementary material, which is available to authorized users.

$\checkmark$ ChangSheng Ma

tougao201801@sina.com

1 Department of Cardiology, Beijing Anzhen Hospital, Capital Medical University, National Clinical Research Center for Cardiovascular Diseases, Beijing, China 